\title{
Hypothyroidism Due to Auto-immune Thyroiditis in a Young Child with Down's Syndrome
}

\author{
F. HARRIS and E. KOUTSOULIERIS \\ From the Department of Child Health, University of Sheffield
}

Evidence suggesting an increased incidence of thyroid disorders in patients with Down's syndrome is accumulating (Mellon, Pay, and Green, 1963; Burgio, Severi, Rossoni, and Vaccaro, 1965; Fialkow, Uchida, Hecht, and Motulsky, 1965). In this paper we report the association of trisomy 21, with severe acquired hypothyroidism due to autoimmune thyroiditis in a girl of $3 \frac{3}{4}$ years.

\section{Case Report}

An infant girl was diagnosed at birth as having Down's syndrome. Cytogenetic studies demonstrated a normal karyotype in the mother and trisomy 21 in the patient (Dr. E. Blank).

In February 1963 the patient, aged 9 months, was admitted to the Children's Hospital, Sheffield, with acute laryngo-tracheo-bronchitis. At this time she was noted to have typical features of Down's syndrome (Fig. 1). Her course in hospital was uneventful and she was discharged after 7 days.

She was readmitted in March 1966 at the age of 3 years and 10 months. On this occasion the presenting symptoms were pallor and constipation. The parents

Received November 17, 1966. noted that from the age of 2 years there was coarsening of the facial features (Fig. 2) and increasing sluggishness in her behaviour. She could walk with support at 15 months, but had progressed no further, and shortly before admission had become unable to walk even with support. In the three months before admission yellow areas of discoloration in the wrist creases and on the knees and elbows had become marked, and constipation had become very severe.

Family history. The mother had had three pregnancies. The first terminated spontaneously at 28 weeks with delivery of a male infant with multiple congenital abnormalities, who survived for one hour. The propositus is the product of the second pregnancy when the maternal and paternal ages were 27 years. The third pregnancy terminated spontaneously with the birth of a normal full-term male infant.

Examination. The patient was lethargic, underweight $(10 \mathrm{~kg}$.), and dwarfed $(74 \mathrm{~cm}$.). Her facial features were of both Down's syndrome and severe hypothyroidism (Fig. 3). The thyroid gland was not palpable. There was bright yellow staining in the creases on the palmar aspect of the wrists and similar patches of discoloration on the knees. The left second toe was conspicuously

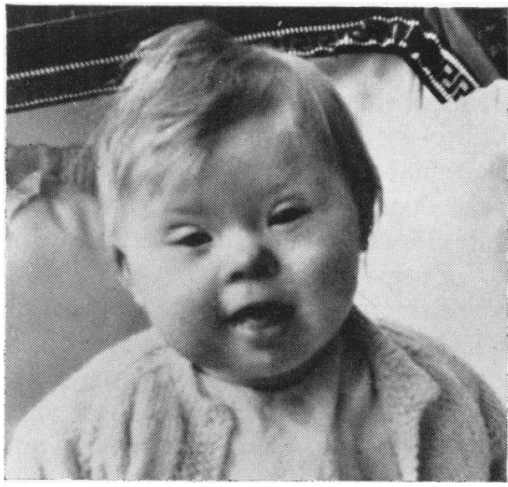

FIG. 1.-Patient, age 1 year.

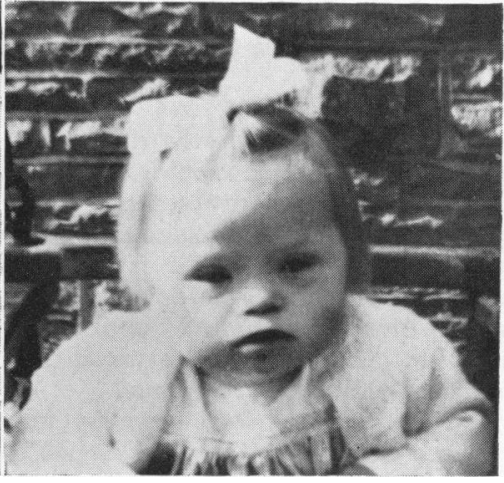

FIG. 2.-Patient, age 2 years 3 months. 


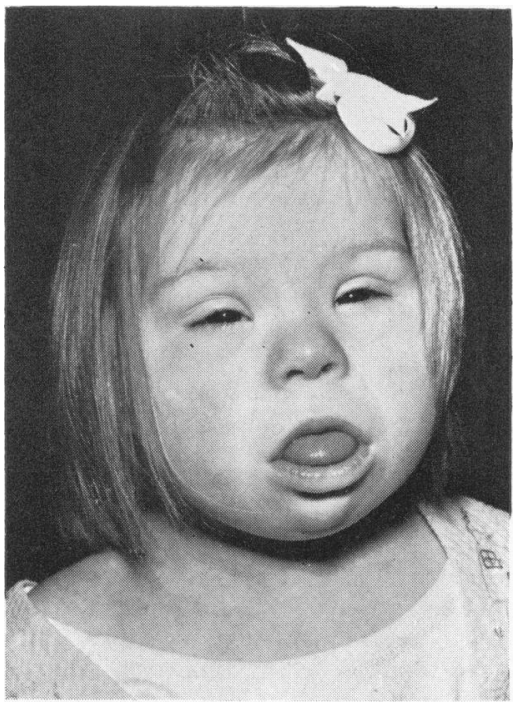

FIG. 3.-Patient, age 3 years 10 months.

enlarged and yellow. The pulse rate was 80 per minute. The heart and lungs were normal. The liver was enlarged to $2.5 \mathrm{~cm}$. below the costal margin and was firm. All the reflexes were present but not brisk. She was unable to stand unsupported and did not attempt to crawl. When placed prone she would lift her head for a short while and then lie completely flat. Her favourite position was to sit upright and rock to and fro.

Investigations. Urinanalysis was within normal limits. Hb 9.7 g. $/ 100 \mathrm{ml}$; ESR $50 \mathrm{~mm}$. $/ \mathrm{hr}$; total serum lipoids 2.5 g./100 ml.; cholesterol 1250 mg./100 ml.; protein bound iodine $2.5 \mu \mathrm{g} . / 100 \mathrm{ml}$.; creatine phosphokinase $7 \cdot 3 \mu \mathrm{mole} / \mathrm{ml}$. hr.; alkaline phosphatase 4 King units; sodium $134 \mathrm{mEq} / 1$.; potassium 4.9 mEq/l., and bicarbonate $19 \mathrm{mEq} / 1$; urea $31 \mathrm{mg} . / 100 \mathrm{ml}$; total protein $6.6 \mathrm{~g} . / 100 \mathrm{ml}$. Electrophoresis of plasma showed moderate increase in $a_{2}$ and $\gamma$-globulin. Urinary 17-hydroxycorticosteroids 0.08 mg./24 hr., and 17-ketosteroids $0.05 \mathrm{mg} . / 24 \mathrm{hr}$; urinary oestriol $8 \mu \mathrm{g}$. $/ 24 \mathrm{hr}$., oestrone $2 \mu \mathrm{g}$. $/ 24 \mathrm{hr}$., and oestradiol $2 \mu \mathrm{g}$. $/ 24 \mathrm{hr}$.

Pituitary gonadotrophins were $<0.4$ i.u./day. Plasma thyrotrophic hormone was clearly detectable by the McKenzie bio-assay method in keeping with the usual experience in adult primary myxoedema (Dr. D. Monro). Thyroid antibodies: thyroglobulin tanned cell agglutination titre 1/10; colloid antibodies immunofluorescent positive; cytoplasmic antibodies immunofluorescent positive; cytoplasmic antibodies complement-fixation titre $1 / 256$; no gastric parietal cell or non-organ-specific auto-antibodies were found.

Serum from the mother and sib was negative for thyroid and gastric auto-antibodies (Dr. D. Doniach).

$X$-ray examination of the wrist showed a bone age of 2 years (CA 3 10/12 years); and of the pelvis revealed shallow acetabula and iliac angles; no epiphysial dysgenesis was seen.

The electrocardiogram was normal.

Treatment was started with L-thyroxine in a dose of $25 \mu \mathrm{g}$. daily and increased to $0.1 \mathrm{mg}$. daily. After 10 weeks of treatment the creatine kinase was $2 \cdot 1 \mu \mathrm{mole} / \mathrm{ml}$. hr., alkaline phosphatase $16 \mathrm{King}$ units, cholesterol 163 $\mathrm{mg} . / 100 \mathrm{ml}$., and protein bound iodine $10.7 \mu \mathrm{g} . / 100 \mathrm{ml}$. She became more alert within a few days of starting treatment, and within four months was able to walk without support and say single words with meaning. The facial features are now quite clearly those of Down's syndrome (Fig. 4).

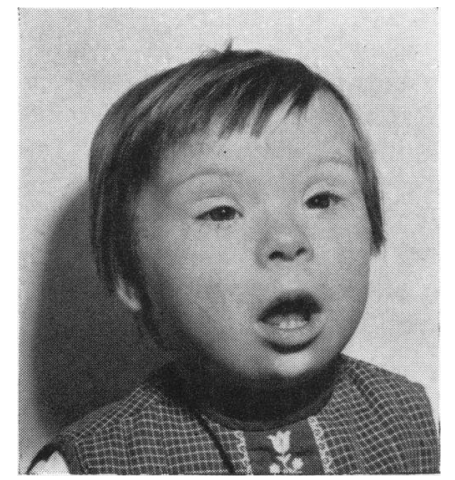

FIG. 4.-Patient, age 4 years 2 months.

\section{Discussion}

The patient described in this paper had trisomy 21 and gross acquired hypothyroidism. The finding of high titres of thyroid auto-antibodies was considered diagnostic of severe auto-immune thyroid disease. The coincidence of these two conditions in a patient of this age has to the best of our knowledge not been previously described. Mellon et al. (1963) reported a 29-year-old patient with Down's syndrome and myxoedema due to auto-immune thyroiditis. In their investigation into the occurrence of thyroid auto-antibodies among other patients with Down's syndrome, they found that 7 out of 35 patients $(20 \%)$ had thyroid auto-antibodies in their serum, but only one had clinical thyroid disease. None of the 35 patients in the control group, matched for age, sex, and intelligence, had thyroid auto-antibodies detectable.

Burgio et al. (1965) were able to demonstrate a positive test for thyroid auto-antibodies in 7 out of 12 children with Down's syndrome and in 6 of the mothers, while in the group of 48 controls, among whom were 18 children and their mothers, they found 3 sero-positive children and 5 sero-positive mothers.

Similarly, Fialkow et al. (1965) found a strikingly 
higher incidence of sero-positive results in $29 \%$ of a group of mothers with an affected child, but in only $9 \%$ of other mothers in the child-bearing age. No increased frequency of sero-positive fathers was found. It is unlikely that the association of autoimmune thyroiditis and Down's syndrome in the propositus is coincidental.

In spite of the above finding, the presence of hypothyroidism due to auto-immune thyroiditis in young patients with Down's syndrome appears to be a rarity. Isolated case reports of hypothyroidism in Down's syndrome have been published (Talbot, Sobel, McArthur, and Crawford, 1952; Esen and Mautner, 1957; Lunde, 1959; Hubble, 1963; Hayles, Hinrichs, and Tauxe, 1965). No information about thyroid antibodies is mentioned in these reports. In this connexion it is of interest that in the patient documented by Hayles et al. (1965), the erythrocyte sedimentation rate was raised $(56 \mathrm{~mm}$./ hr.).

The patients reported by Lunde (1959), Hubble (1963), and Hayles et al. (1965) had primary hypothyroidism and exhibited precocious menstruation, This has been ascribed in part to hormonal overlap in the pituitary feedback mechanism (Van Wyk and Grumbach, 1960). Although our patient had a grossly raised thyroid stimulating hormone, no clinical evidence of sexual precocity was found, and the follicular stimulating hormone level in the urine was less than 0.4 i.u./day, but the level of urinary oestriol was considerably raised for her age (Eberlein, Bongiovanni, and Francis, 1958).

There have been fairly numerous studies of thyroid function in patients with Down's syndrome who were clinically euthyroid. The protein-bound iodine has invariably been within the normal range (Cottino, Ferraris, and Coda, 1956; McGirr and Murray, 1956; Bellack and Albaum, 1957). Investigations using radioactive iodine have generally given similar results. The ${ }^{131}$ I uptake at 24 hours was found to be normal in a study of 50 patients with Down's syndrome and 68 euthyroid patients with mental retardation of various causes (Friedman, 1955). No six-hour uptake recordings were done and many of the patients with Down's syndrome had previously been on thyroid therapy which had been stopped 14 days before the test.

Kurland, Fishman, Hamolsky, and Freedberg (1957) obtained normal values for the 24-hour uptake in 21 patients with Down's syndrome, but the turnover rate of ${ }^{131}$ I by the thyroid was significantly faster than in the euthyroid group and the in vitro erythrocyte uptake of 131I-labelled triiodothyronine was raised. The significance of the increased rate of ${ }^{131}$ I turnover is uncertain, but the explanation may lie in the presence of localized areas of hyperplasia in the thyroid gland found by Benda (1946) in $20 \%$ of his subjects. Whether they are in turn related to the presence of thyroid autoantibodies is unknown and worth further study.

Gonadal dysgenesis is a further example of an aneuplojd state in which Hashimoto's disease (Spakes and Motulsky, 1963) and thyroid autoantibodies have been found (Williams, Engel, and Forbes, 1964). The altered thyroid function in Klinefelter's syndrome (Barr, Shaver, Carr, and Plunkett, 1960; Carr, Barr, Plunkett, Grumbach, Morishima, and Chu, 1961; Davis, Canfield, Herman, and Goler, 1963) does not appear to be related to an auto-immune mechanism. Day and Wright (1964) were unable to demonstrate significantly high titres in 16 patients with abnormalities of the sex chromosome complement of the Klinefelter variety; nor were they present in parents of patients with chromatin positive Klinefelter's syndrome (Ferguson-Smith, Anderson, Frøland, and Gray, 1966).

Fialkow (1964) suggested three possible explanations for the association between aneuploid conditions and thyroid auto-antibodies. First, the chromosomal aberration may predispose to the development of auto-antibodies in the patients. The demonstration of auto-antibodies in the sera of phenotypically normal relatives does not favour this suggestion, but extensive cytogenetic studies of sero-positive mothers have not been reported. Secondly, the presence of immunological aberrations in the parent may predispose to aneuploidy. Thirdly, a common factor may be responsible for both the immunological aberrations and the aneuploidy. The limited family study in this patient revealed a normal karyotype in the mother and no gastric or thyroid auto-antibodies were demonstrated in her serum or that of the younger sib.

The subject of thyroiditis in childhood has recently been reviewed by Leboeuf and Ducharme (1966). It is apparent that the true incidence of thyroiditis in childhood is unknown, but surveys in Boston (Saxena and Crawford, 1962), Philadelphia (Leboeuf and Bongiovanni, 1964), and Gothenburg (Nilsson and Doniach, 1964) have shown that thyroiditis is responsible for approximately $50 \%$ of goitres in euthyroid children. By 1965 only 158 cases of thyroiditis had been reported in the English and French reports, while 500 cases of thyroid carcinoma had been described by 1961 (Leboeuf and Ducharme, 1966).

It is likely that a greater awareness of the part played by thyroiditis in disorders of childhood 
thyroid function would lead to the diagnosis being made more often.

\section{Summary}

A young child with trisomy 21 and acquired hypothyroidism due to auto-immune thyroiditis is described. Limited family studies were negative for chromosomal and immunological abnormalities. Thyroid function tests have generally been normal in Down's syndrome, despite an increased incidence of thyroid auto-antibodies. The pathogenesis of auto-immune thyroiditis and the presence of thyroid auto-antibodies in Down's syndrome is at present unknown.

We should like to thank Professor R. S. Illingworth for advice and encouragement, Dr. D. Doniach for thyroid auto-antibody studies, Dr. D. Monro for thyroid stimulating hormone estimations, Dr. E. Blank for cytogenetic studies, and Dr. G. Pennington for urinary steroid determinations.

\section{REFERENCES}

Barr, M. L., Shaver, E. L., Carr, D. H., and Plunkett, E. R. (1960). The chromatin-positive Klinefelter syndrome among patients in mental deficiency hospitals. F. ment. Defic. Res., 4, 89.

Bellack, S., and Albaum, J. (1957). The thyroid function in mongoloids as determined by the measurement of protein bound iodine. Amer. F. ment. Defic., 62, 275.

Benda, C. (1946). Mongolism and Cretinism. Grune and Stratton, New York.

Burgio, G. R., Severi, F., Rossoni, R., and Vaccaro, R. (1965). Mongolism and thyroid autoimmunity. Lancet, $1,166$.

Carr, D. H., Barr, M. L., Plunkett, E. R., Grumbach, M. M., Morishima, A., and Chu, E. H. Y. (1961). An XXXY sex chromosome complex in Klinefelter subjects with duplicated sex chromatin. F. clin. Endocr., 21, 491.

Cottino, F., Ferraris, G. M., and Coda, G. (1956). Thyroidal function in mongolism. ibid., 16, 830 .

Davis, T. E., Canfield, C. J., Herman, R. H., and Goler, D. (1963). Thyroid function in patients with aspermiogenesis and testicular tubular sclerosis. New Engl. F. Med., 268, 178.

Day, R. W., and Wright, S. W. (1964). Thyroid autoantibodies and sex-chromosome abnormalities. Lancet, 1, 667.
Eberlein, W. R., Bongiovanni, A. M., and Francis, C. M. (1958). A simplified method for the routine measurement of urinary estriol. F. clin. Endocr., 18, 1274.

Esen, F. M., and Mautner, H. (1957). Hypo- and hyperthyroidism in mongolism. Arch. Pediat., 74, 291.

Ferguson-Smith, M. A., Anderson, J. R., Frøland, A., and Gray, K. G. (1966). Frequency of autoantibodies in patients with chromatin-positive Klinefelter's syndrome and their parents. Lancet, 2, 566.

Fialkow, P. J. (1964). Autoimmunity: a predisposing factor to chromosomal aberrations ? ibid., 1, 474.

—, Uchida, I. A., Hecht, F., and Motulsky, A. G. (1965). Increased frequency of thyroid autoantibodies in mothers of patients with Down's syndrome. ibid., 2, 868.

Friedman, A. (1955). Radioiodine uptake in children with mongolism. Pediatrics, 16, 55.

Hayles, A. B., Hinrichs, W. L., and Tauxe, W. N. (1965). Thyroid disease among children with Down's syndrome (mongolism). ibid., 36, 608 .

Hubble, D. (1963). Precocious menstruation in a mongoloid child with hypothyroidism-hormonal overlap. F. clin. Endocr., 23, 1302.

Kurland, G. S., Fishman, J., Hamolsky, M. W., and Freedberg, A. S. (1957). Radioisotope study of thyroid function in 21 mongoloid subjects including observations in 7 parents. ibid., 17, 552 .

Leboeuf, G., and Bongiovanni, A. M. (1964). Thyroiditis in childhood. Advanc. Pediat., 13, 183.

- and Ducharme, J. R. (1966). Thyroiditis in children. Pediat. Clin. N. Amer., 13, 19.

Lunde, P. K. M. (1959). Samtidig forekomst av mongolisme og hypothyreose. $T$. norske Lageforen., 79, 394.

McGirr, E. M., and Murray, I. P. C. (1956). Thyrotoxicosis in a mongol. f. clin. Endocr., 16, 160.

Mellon, J. P., Pay, B. Y., and Green, D. M. (1963). Mongolism and thyroid autoantibodies. F. ment. Defic. Res., 7, 31.

Nilsson, L. R., and Doniach, D. (1964). Auto-immune thyroiditis in children and adolescents. I. Clinical studies. Acta paediat. (Uppsala), 53, 255.

Saxena, K. M., and Crawford, J. D. (1962). Juvenile lymphocytic thyroiditis. Pediatrics, 30, 917.

Spakes, R. S., and Motulsky, A. S. (1963). Hashimoto's disease in Turner's syndrome with isochromosome X. Lancet, 1, 947.

Talbot, N. B., Sobel, E. H., McArthur, J. W., and Crawford, J. D. (1952). Functional Endocrinology: From Birth Through Adolescence, p. 24. Harvard University Press, Cambridge, Massachusetts.

Van Wyk, J. J., and Grumbach, M. M. (1960). Syndrome of precocious menstruation and galactorrhea in juvenile hypothyroidism: an example of hormonal overlap in pituitary feedback. F. Pediat., 57, 416.

Williams, E. D., Engel, E., and Forbes, A. P. (1964). Thyroiditis and gonadal dysgenesis. New Engl. F. Med., 270, 805. 